\title{
Critical care admission of South African (SA) surgical patients: Results of the SA Surgical Outcomes Study
}

\author{
D L Skinner, ${ }^{1}$ FCS (SA), MMed (Surg), Cert Crit Care (SA); K de Vasconcellos, ${ }^{1}$ FCA (SA), Cert Crit Care (SA); \\ R Wise, ${ }^{1}$ FCA (SA), MMed (Anaes), Cert Crit Care (SA); T M Esterhuizen, ${ }^{2}$ MSc (Epidemiology); C Fourie, ${ }^{3}$ MMed (Anaes); \\ A Goolam Mahomed, ${ }^{4}$ FCP (SA); P D Gopalan, ${ }^{1}$ FCA (SA); I Joubert, ${ }^{5}$ FCA (SA); H Kluyts, ${ }^{6}$ MMed (Anaes); \\ L R Mathivha, ${ }^{7}$ FCPaed (SA), Cert Crit Care; DBS (BM); B Mrara, ${ }^{8}$ FCA (SA); J P Pretorius, ${ }^{9}$ FCS (SA); G Richards, ${ }^{7}$ PhD; \\ O Smith, ${ }^{10}$ FCA (SA), Cert Crit Care (SA); M G L Spruyt, ${ }^{11}$ MMed (Chir); R M Pearse, ${ }^{12}$ MD (Res); T E Madiba, ${ }^{13} \mathrm{PhD} ; \mathbf{B}$ M Biccard ${ }^{14} \mathrm{PhD}$; \\ on behalf of the South African Surgical Outcomes Study (SASOS) investigators
}

\author{
${ }^{1}$ Discipline of Anaesthesiology and Critical Care, School of Clinical Medicine, University of KwaZulu-Natal, Durban, South Africa \\ ${ }^{2}$ Centre for Evidence-Based Health Care, Faculty of Medicine and Health Sciences, Stellenbosch University, Cape Town, South Africa \\ ${ }^{3}$ Department of Critical Care, Faculty of Medicine and Health Sciences, Stellenbosch University, Cape Town, South Africa \\ ${ }^{4}$ Department of Critical Care, Sefako Makgatho Health Sciences University, Pretoria, South Africa \\ ${ }^{5}$ Division of Critical Care, Department of Anaesthesia and Perioperative Medicine, Faculty of Health Sciences, University of Cape Town, South Africa \\ ${ }^{6}$ Department of Anaesthesiology, Sefako Makgatho Health Sciences University, South Africa \\ ${ }^{7}$ Department of Critical Care, Faculty of Health Sciences, University of the Witwatersrand, Johannesburg, South Africa \\ ${ }^{8}$ Department of Anaesthesiology, Faculty of Health Sciences, Walter Sisulu University, Mthatha, South Africa \\ ${ }^{9}$ Department of Critical Care, Faculty of Health Sciences, University of Pretoria, South Africa \\ ${ }^{10}$ Department of Anaesthesia, Faculty of Health Sciences, University of the Witwatersrand, Johannesburg, South Africa \\ ${ }^{11}$ Department of Critical Care, Faculty of Health Sciences, University of the Free State, Bloemfontein, South Africa \\ ${ }^{12}$ Department of Intensive Care Medicine, Queen Mary University of London, UK \\ ${ }^{13}$ Department of Surgery and Gastrointestinal Cancer Research Centre, School of Clinical Medicine, University of KwaZulu-Natal, Durban, South Africa \\ ${ }^{14}$ Department of Anaesthesia and Perioperative Medicine, Faculty of Health Sciences, University of Cape Town, South Africa
}

Corresponding author: B M Biccard (bruce.biccard@uct.ac.za)

\begin{abstract}
Background. Appropriate critical care admissions are an important component of surgical care. However, there are few data describing postoperative critical care admission in resource-limited low- and middle-income countries.

Objective. To describe the demographics, organ failures, organ support and outcomes of non-cardiac surgical patients admitted to critical care units in South Africa (SA).

Methods. The SA Surgical Outcomes Study (SASOS) was a 7-day national, multicentre, prospective, observational cohort study of all patients $\geq 16$ years of age undergoing inpatient non-cardiac surgery between 19 and 26 May 2014 at 50 government-funded hospitals. All patients admitted to critical care units during this study were included for analysis.

Results. Of the 3927 SASOS patients, 255 (6.5\%) were admitted to critical care units; of these admissions, 144 (56.5\%) were planned, and $111(43.5 \%)$ unplanned. The incidence of confirmed or strongly suspected infection at the time of admission was $35.4 \%$, with a significantly higher incidence in unplanned admissions $(49.1 \mathrm{v} .24 .8 \%, p<0.001)$. Unplanned admission cases were more frequently hypovolaemic, had septic shock, and required significantly more inotropic, ventilatory and renal support in the first 48 hours after admission. Overall mortality was $22.4 \%$, with unplanned admissions having a significantly longer critical care length of stay and overall mortality $(33.3 \mathrm{v} .13 .9 \%, p<0.001)$. Conclusion. The outcome of patients admitted to public sector critical care units in SA is strongly associated with unplanned admissions. Adequate 'high care-dependency units' for postoperative care of elective surgical patients could potentially decrease the burden on critical care resources in SA by 23\%. This study was registered on ClinicalTrials.gov (NCT02141867).
\end{abstract}

S Afr Med J 2017;107(5):411-419. DOI:10.7196/SAMJ.2017.v107i5.11455

The number of surgical patients requiring access to critical care units represents a large resource burden, which is particularly marked in low- and middle-income countries that have a limited number of critical care beds. ${ }^{[1]}$ This is typified by the situation in South African (SA) government-funded hospitals. ${ }^{[2]}$ The recent SA Surgical Outcomes Study (SASOS) was a prospective observational study of peri-operative outcomes in SA surgical patients, which showed that the most important population-attributable risk for mortality and critical care admission was urgent and emergent surgery ${ }^{[3]}$ Comparison of the SASOS data with those of the European Surgical Outcomes Study $(\text { EuSOS })^{[4]}$ showed that there had been significantly fewer critical care admissions for SA patients, more unplanned admissions and a higher critical care mortality. ${ }^{[3]}$ An identical definition of a critical care unit was used in both studies, i.e. a facility routinely capable of admitting patients requiring invasive ventilation overnight and, as such, comparison between the SASOS and EuSOS data is acceptable.

Given the differences in critical care resources, and the observed differences in the characteristics of the critical care admissions in SA relative to those in Europe, the objective of this study was to describe the demographics, organ failures, organ support and outcomes of non-cardiac surgical patients admitted to critical care units in SA during the SASOS study period. These outcome data would potentially be relevant to resource-limited environments and perhaps provide information as to where interventions would potentially 
be beneficial in decreasing critical care-associated morbidity and mortality.

\section{Methods}

The methods of SASOS have previously been described in detail. ${ }^{[3]}$ Briefly, this was a 7-day, SA, multicentre, prospective, observational cohort study of patients aged $\geq 16$ years undergoing inpatient, noncardiac, non-obstetric surgery, which included elective and emergency surgery. Fifty hospitals across all provinces of SA participated (ClinicalTrials.gov (NCT02141867)). Hospital-specific data that were collected included the number of operating rooms and the number and level of critical care beds. Ethics approval was obtained for all sites. A waiver of consent was approved for all sites, with the exclusion of the University of the Witwatersrand, Johannesburg, and the Free State Provincial Administration, Bloemfontein, SA, both of which stipulated that informed consent was required from all patients, with a deferred consent for those not able to give consent prior to surgery. We intended to recruit all eligible patients to minimise selection bias.

Recruitment ran from 07h00 on 19 May to 06h59 on 26 May 2014. All patients $\geq 16$ years of age (except for the University of the Witwatersrand hospitals, whose ethics committee only approved participation of patients $\geq 18$ years) undergoing elective or non-elective inpatient noncardiac surgery during the 7-day recruitment period were eligible. The following were excluded: planned, day surgery, cardiac surgery, and radiological procedures not requiring anaesthesia, and obstetric patients.

The EuSOS dataset was adopted with minor changes. The major deviation from the EuSOS protocol was to censor the study at 30 days as opposed to 60 days, because most of the deaths had occurred within 30 days of surgery in EuSOS. In addition, we included neurosurgical patients. We collected the same potential risk factors as EuSOS for in-hospital and critical care mortality, but added the primary indication for surgery, utilising the following categories: (i) communicable diseases; (ii) non-communicable diseases; and (iii) injuries. To ensure consistency in data definitions and interpretation, the principal investigators (BMB and TEM) made site visits to meet with local investigators and provide study educational material. The website provided educational support and a regularly updated frequently asked questions' webpage. The case report forms (CRFs) were available on the study website.

Data were collected on paper CRFs and were anonymised by unique numeric codes generated during data transcription onto an internet-based CRF. Each patient could only be identified on the electronic CRF by their numeric code. The co-ordinating study team could not trace data back to an individual patient without contact with the local team. Access to the data entry system was username and password protected. All electronic data transfer was encrypted using a secure protocol. This study was reported per the STROBE (STrengthening the Reporting of OBservational studies in Epidemiology) statement. ${ }^{[5]}$

\section{Statistical analysis}

This study is a subgroup analysis of the 255 SASOS patients admitted to critical care units. ${ }^{[3]}$ The data collected were parameters routinely collected in the critical care unit. Categorical variables were described as proportions and compared using $\chi^{2}$ tests, Fisher's exact tests, Pearson's $\chi^{2}$ tests or $\chi^{2}$ tests with Yates's correction, as appropriate. Continuous variables were described as means and standard deviations (SDs) if normally distributed or otherwise medians and interquartile ranges (IQRs).

Acute kidney injury (AKI) was defined per the Kidney Disease Improving Global Outcomes (KDIGO) criteria $^{[6]}$ using the serum creatinine levels for calculation of the appropriate KDIGO stage. Missing values for continuous variables necessary for the calculation of the KIDGO and Sequential Organ Failure Assessment (SOFA) scores $^{[7]}$ were imputed using multiple imputation with fully conditional specification. A maximum of 1000 iterations, 200 case draws and 20 parameter draws was specified. Two imputations datasets were computed, and the dataset closest to the original mean values was used. Comparisons of continuous variables between groups were performed using unpaired $t$-tests or one-way analysis of variance (ANOVA) as appropriate. Univariate analysis was performed to test for risk factors associated with critical care admission and/or in-hospital death.

Generalised linear mixed models using a logit link were used to identify independent risk factors for binary outcomes. These included one-level, hierarchical two-level and three-level models to account for the expected correlation in outcomes in hospitals and provinces. We used a three-level generalised mixed model, with patients being at the first level, hospital at the second level and province at the third level. Results are reported as adjusted odds ratios (ORs) with 95\% confidence intervals (CIs). All factors with a univariate association of $p<0.05$ were entered into the models. Univariate and multivariable statistical analyses were performed using SPSS version 21 (IBM Corp., USA).

\section{Results}

SASOS included 50 government-funded hospitals, 8 district hospitals, 41 regional or tertiary hospitals and 1 specialised services hospital. Critical care units were available in $44(88 \%)$ hospitals. These units provided a median of 7 (IQR 4 - 16) critical care beds, with a median of $6(2-10)$ beds with access to mechanical ventilation and $3(0-6)$ without mechanical ventilation.

There was a $97.7 \%$ recruitment of eligible patients (3 927/4 021). A total of 255 (6.5\%) patients were admitted to critical care beds; of these, 144 (56.5\%) were planned and 111 (43.5\%) unplanned admissions.

The characteristics of the patients admitted to critical care, the primary indications for surgery, surgical site and reasons for critical care admissions are shown in Table 1. There was no statistical difference in the ages of the trauma group for planned v. unplanned admission (mean 36.7 (SD 12.8) v. 34.2 (13.7), $p=0.343$ ). The site of infection for the patients admitted with confirmed or strongly suspected infection is shown in Table 2 .

Table 3 highlights the critical care organ support and severity of critical care illness. SOFA score, KDIGO scores and $\mathrm{PaO}_{2} / \mathrm{FiO}_{2}$ ratio are listed as organ dysfunction scores. Very few critically ill patients (2.5\%) were planned to receive renal replacement therapy (RRT) on admission and only $2.3 \%$ received RRT at 48 hours.

The critical care patient outcomes are shown in Table 4. Crude hospital mortality for all patients recruited in SASOS was 3.1\%, and for those admitted to a critical care unit it was $22.4 \%$. Information regarding appropriateness and timing of discharges, planned palliation and withdrawal of critical care therapy were not captured. Mortality following elective surgery was the lowest (5.3\%), and a post-hoc analysis showed that the patients had a median length of stay of $1(0-3)$ day compared with the unplanned admissions (3 (1 - 9) days, $p<0.001)$.

Furthermore, although the critical admissions reported in SASOS were significantly fewer than in EuSOS (6.5 v. 7.7\%, respectively), a significantly higher number of the admissions in SASOS were unplanned compared with those in EuSOS $(p<0.0001)$ and the critical care mortality was significantly higher than the EuSOS data $(22.4 \mathrm{v}$. $14.1 \%) .{ }^{[4]}$ 
The univariate and multivariable associations with critical care mortality are shown in Table 5. Notably, 14 (24.6\%) of deaths occurred in American Society of Anesthesiologists (ASA) 1 or 2 patients. With regard to surgical specialty, $13(22.8 \%)$ deaths followed lower gastrointestinal tract (GIT) surgery, 11 (19.3\%) upper GIT surgery and 7 (12.3\%) vascular surgery. The only independent predictors of critical care mortality were increasing age and urgent or emergent surgery (Table 5).

\section{Discussion}

The main findings of the SASOS critical care cohort showed that comorbidities, severity of illness and outcomes differed between planned and unplanned admissions in SA. Planned admissions were associated with predominantly non-communicable diseases, but also with a significant burden of non-haematological malignancies, both of which require predominantly routine postoperative care. In contrast, unplanned admissions predominantly followed injury. Although the

Table 1. Description of critical care cohort ${ }^{\star}$

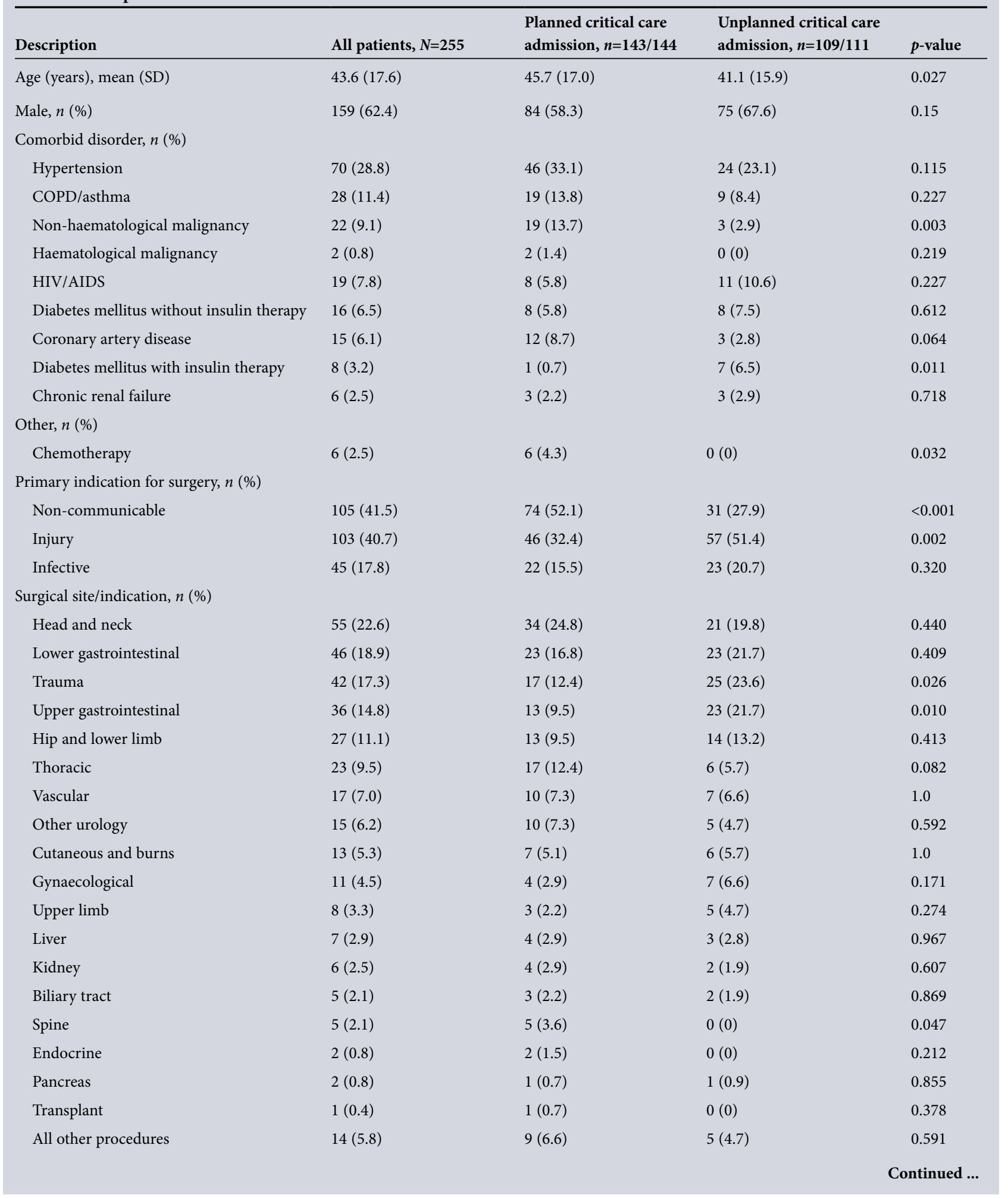


Table 1. (continued) Description of critical care cohort ${ }^{\star}$

\begin{tabular}{|c|c|c|c|c|}
\hline Description & All patients, $N=255$ & $\begin{array}{l}\text { Planned critical care } \\
\text { admission, } n=143 / 144\end{array}$ & $\begin{array}{l}\text { Unplanned critical care } \\
\text { admission, } n=109 / 111\end{array}$ & $p$-value \\
\hline \multicolumn{5}{|l|}{ Reason(s) for critical care admission, $n(\%)$} \\
\hline Routine care & $128(53.6)$ & $102(75.0)$ & $26(25.2)$ & $<0.001$ \\
\hline Nosocomial (hospital-acquired) infection & $33(38.3)$ & $12(35.3)$ & $21(41.2)$ & 0.653 \\
\hline $\begin{array}{l}\text { Confirmed/strongly suspected infection } \\
\text { at critical care admission }\end{array}$ & $86(35.4)$ & $34(24.8)$ & $52(49.1)$ & $<0.001$ \\
\hline Hypovolaemic shock & $53(22.1)$ & $22(16.1)$ & $31(30.1)$ & 0.012 \\
\hline Coma/delirium & $44(18.3)$ & $24(17.6)$ & $20(19)$ & 0.780 \\
\hline Septic shock & $37(15.5)$ & $11(8.1)$ & $26(25.2)$ & $<0.001$ \\
\hline $\begin{array}{l}\text { Respiratory arrest in } 24 \mathrm{~h} \text { before critical } \\
\text { care admission }\end{array}$ & $10(4.1)$ & $2(1.4)$ & $8(7.7)$ & 0.015 \\
\hline Arrhythmia & $7(2.9)$ & $4(3.0)$ & $3(2.9)$ & 0.982 \\
\hline $\begin{array}{l}\text { Cardiac arrest in } 24 \mathrm{~h} \text { before critical } \\
\text { care admission }\end{array}$ & $5(2.0)$ & $1(0.7)$ & $4(3.8)$ & 0.088 \\
\hline Liver failure & $3(1.3)$ & $2(1.5)$ & $1(1.0)$ & 0.726 \\
\hline Severe pancreatitis & $1(0.4)$ & $0(0)$ & $1(1.0)$ & 0.251 \\
\hline
\end{tabular}

Table 2. Site of infection in patients with confirmed or strongly suspected infection at critical care admission

\begin{tabular}{llll}
\hline & $\begin{array}{l}\text { Total, } \\
\text { Site of infection }\end{array}$ & $\begin{array}{l}\text { Planned } \\
\text { admissions, } \\
\boldsymbol{N}=\mathbf{8 4}\end{array}$ & $\begin{array}{l}\text { Unplanned } \\
\text { admissions, } \\
\boldsymbol{n}=\mathbf{5 1}\end{array}$ \\
\hline Wound & 18 & 7 & 11 \\
Lung & 20 & 8 & 12 \\
Urinary & 3 & 2 & 1 \\
Abdominal & 28 & 9 & 19 \\
Other & 15 & 7 & 8 \\
$p=0.756$. & & &
\end{tabular}

SOFA scores are similar between planned and unplanned admissions, patients with unplanned admissions were significantly younger, required significantly more respiratory, cardiovascular and renal organ support, had a longer length of intensive care unit (ICU) stay, and a significantly higher in-hospital mortality after discharge from the ICU. Urgent and emergent surgery was the strongest independent predictor of critical care mortality in SA surgical patients.

These findings reflect the challenges faced by SA critical care clinicians. It demonstrates the strain placed on critical care resources by a triple burden of disease, with non-communicable disease predominating in planned admissions, trauma in unplanned admissions and confirmed or strongly suspected infections being associated with $35 \%$ of all admissions. To improve the outcomes of surgical patients in SA, all three of these burdens of disease need to be addressed.

The time to critical care admission after surgery was also significantly prolonged in the unplanned admission group. These two factors may therefore reflect limited critical resources and/or failure to identify at-risk postoperative patients in the SASOS cohort.

It is therefore important to provide sufficient critical care beds appropriate to the requirements of critical care patients in SA. A possible solution would be to admit postoperative elective surgical patients to a 'high care-dependency unit' as opposed to a critical care unit. This approach would have freed up $23 \%$ of the critical care beds in this study. An exception to this proposal might have to be elective surgical patients undergoing upper or lower GIT surgery, as these groups had a significantly higher mortality $(33.3 \%$ and $16.7 \%$, respectively) than other elective surgical patients.

The morbidity associated with the triple burden of disease, the nature of the critical care admissions and the critical care resources available are important to health policy makers responsible for the planning of critical care requirements. Including the need for other care facilities such as high care-dependency units in resource-limited environments, planning for the necessary expansion of critical care resources needs to consider the associated indications and complications of critical care admissions.

Compared with studies conducted in European, Australian and North American populations, ${ }^{[8,9]}$ SASOS patients were relatively younger, consistent with the low life expectancy in SA. ${ }^{[10]}$ Furthermore, consistent with the HIV pandemic in $\mathrm{SA},{ }^{[11]}$ at least $13.2 \%$ of the SASOS surgical patients had suspected HIV infection, and $7.8 \%$ of patients admitted to critical care units had HIV infection. The HIV infection rate may not be accurate, as the status was not determined for all patients and unconsented testing is still controversial. The prognostic implications of HIV in surgical patient outcomes have already been explored by some authors, ${ }^{[12-15]}$ with conflicting results, but were not found to be associated with surgical mortality in $\operatorname{SASOS}^{[3]}$ or in patients admitted to critical care units.

The sepsis rate in critical care admissions in SA is of concern, with $35.4 \%$ of patients having suspected or confirmed infection on ICU admission. The rate of nosocomial sepsis on admission to ICU was also high (38.3\%). ${ }^{[16,17]}$ This highlights the need for early recognition and implementation of infection control procedures and basic management strategies to improve the outcome of those with sepsis or septic shock. Implementation of these strategies prior to surgery may improve survival, particularly if patients are referred early to a facility delivering an appropriate level of care.

Mortality was high in patients who had undergone upper GIT surgery, with several these being unplanned admissions. Unfortunately, 
Table 3. Organ support and severity of disease during critical care admission*

\begin{tabular}{|c|c|c|c|c|}
\hline & All patients, $N=255$ & $\begin{array}{l}\text { Planned critical care } \\
\text { admissions, } n=144\end{array}$ & $\begin{array}{l}\text { Unplanned critical care } \\
\text { admissions, } n=111\end{array}$ & $p$-value \\
\hline \multicolumn{5}{|l|}{ Critical care organ support, $n(\%)$} \\
\hline Invasive ventilation at $1 \mathrm{~h}$ & $143(58.6)$ & $64(46.4)$ & $79(74.5)$ & $<0.001$ \\
\hline Invasive ventilation at $24 \mathrm{~h}$ & $111(49.8)$ & $44(35.5)$ & $67(67.7)$ & $<0.001$ \\
\hline Invasive ventilation at $48 \mathrm{~h}$ & $77(44.0)$ & $24(26.4)$ & $53(63.1)$ & $<0.001$ \\
\hline $\begin{array}{l}\text { Plan made at critical care admission } \\
\text { for renal replacement therapy }\end{array}$ & $6(2.5)$ & $5(3.7)$ & $1(0.9)$ & 0.175 \\
\hline Renal replacement therapy at $24 \mathrm{~h}$ & $5(2.3)$ & $1(0.8)$ & $4(4.0)$ & 0.116 \\
\hline Renal replacement therapy at $48 \mathrm{~h}$ & $4(2.3)$ & $0(0)$ & $4(4.8)$ & 0.036 \\
\hline Inotropes at $1 \mathrm{~h}$ & $54(22.8)$ & $22(16.5)$ & $32(30.8)$ & 0.012 \\
\hline Inotropes at $24 \mathrm{~h}$ & $46(20.9)$ & $18(14.9)$ & $28(28.3)$ & 0.019 \\
\hline Inotropes at $48 \mathrm{~h}$ & $29(16.9)$ & $11(12.2)$ & $18(21.4)$ & 0.109 \\
\hline \multicolumn{5}{|l|}{ Severity of disease: SOFA, mean (SD) } \\
\hline SOFA score at $1 \mathrm{~h}$ & $10(3)$ & $10(3)$ & $10(4)$ & 0.90 \\
\hline SOFA score at $24 \mathrm{~h}$ & $12(4)$ & $11(4)$ & $12(4)$ & 0.50 \\
\hline SOFA score at $48 \mathrm{~h}$ & $9(4)$ & $8(3)$ & $10(5)$ & 0.32 \\
\hline \multicolumn{5}{|l|}{ Severity of disease: Renal, $n(\%)$} \\
\hline \multicolumn{5}{|l|}{ KDIGO score in 1st hour } \\
\hline Stage 1 & $6(3.9)$ & $2(2.4)$ & $4(5.6)$ & 0.36 \\
\hline Stage 2 & $3(1.9)$ & $1(1.2)$ & $2(2.8)$ & - \\
\hline Stage 3 & $9(5.8)$ & $3(3.7)$ & $6(8.3)$ & - \\
\hline \multicolumn{5}{|l|}{ KDIGO score at $24 \mathrm{~h}$} \\
\hline Stage 1 & $15(9.6)$ & $9(10.6)$ & $6(8.3)$ & 0.28 \\
\hline Stage 2 & $6(3.8)$ & $4(4.7)$ & $2(2.8)$ & - \\
\hline Stage 3 & $11(7.0)$ & $3(3.5)$ & $8(11.1)$ & - \\
\hline \multicolumn{5}{|l|}{ KDIGO score at $48 \mathrm{~h}$} \\
\hline Stage 1 & $8(6.5)$ & $4(6.7)$ & $4(6.3)$ & 0.04 \\
\hline Stage 2 & $8(6.5)$ & $6(10.0)$ & $2(3.2)$ & - \\
\hline Stage 3 & $10(8.1)$ & $1(1.7)$ & $9(14.3)$ & - \\
\hline \multicolumn{5}{|l|}{ Severity of disease: } \\
\hline \multicolumn{5}{|l|}{ Respiratory, median (IQR) } \\
\hline $\mathrm{PaO}_{2} / \mathrm{FiO}_{2}$ at $1 \mathrm{~h}$ & $269(195-373)$ & $286(210-384)$ & $253(179-360)$ & 0.15 \\
\hline $\mathrm{PaO}_{2} / \mathrm{FiO}_{2}$ at $24 \mathrm{~h}$ & $275(207-356)$ & $296(224-361)$ & $256(197-341)$ & 0.04 \\
\hline $\mathrm{PaO}_{2} / \mathrm{FiO}_{2}$ at $48 \mathrm{~h}$ & $276(216-319)$ & $294(230-360)$ & $275(195-372)$ & 0.32 \\
\hline
\end{tabular}

these data do not allow differentiation between unexpected surgical emergencies (such as a portal hypertensive or peptic ulcer-related bleed) or elective patients with complications during or after surgery, who may have benefited from a more extensive preoperative work-up. As the exact type and extent of the surgery was unknown, it may be a useful signal to explore in future studies of peri-operative mortality.

The relatively high SOFA scores reflect a population with significant organ dysfunction and predicted mortality. ${ }^{[18]}$ The incidence of mechanical ventilation was low, suggesting that many patients were admitted to critical care units for monitoring and/or cardiovascular support only. This raises questions regarding the distribution and use of critical care resources in SA and highlights the need for high caredependency beds to be included in the planning of future critical care services. It is not surprising that the unplanned admissions required more frequent and prolonged duration of ventilation and inotropic support.

More than $10 \%$ of patients were diagnosed with AKI on admission, which increased to $21.1 \%$ at 48 hours. This is similar to the percentage in other studies with mixed critical care populations, which report an incidence of $22-35 \% \cdot{ }^{[1,20]}$ Patients with unplanned admissions were more likely to have higher-grade AKI. Only $2.3 \%$ of patients had planned RRT at 48 hours, despite a significant number being referred to critical care with AKI, and $14.6 \%$ having stage 2 or $3 \mathrm{AKI}$ at 48 hours. Although the AKI stage is not an indication to start RRT, these findings may represent either a lack of dialysis facilities in SA or a reluctance to start dialysis early owing to controversy regarding the benefits of early v. later initiation. ${ }^{[21-24]}$ 
Table 4. Critical care patient outcomes

\begin{tabular}{|c|c|c|c|c|}
\hline Outcomes & All patients, $N=255$ & $\begin{array}{l}\text { Planned critical care } \\
\text { admission, } n=144\end{array}$ & $\begin{array}{l}\text { Unplanned critical care } \\
\text { admission, } n=111\end{array}$ & $p$-value \\
\hline Mortality & $57(22.4)$ & $20(13.9)$ & $37(33.3)$ & $<0.001$ \\
\hline Length of stay & $6.4(8.9)$ & $5.0(7.3)$ & $8.2(10.3)$ & 0.008 \\
\hline Planned discharge & $202(83.1)$ & $120(87.6)$ & $82(77.4)$ & 0.039 \\
\hline $\begin{array}{l}\text { Post-discharge mortality in patients } \\
\text { discharged alive from critical care }\end{array}$ & $12(6.2)$ & $3(2.5)$ & $9(12)$ & 0.008 \\
\hline
\end{tabular}

Table 5. Predictors of critical care mortality*

\begin{tabular}{|c|c|c|c|c|c|c|}
\hline Predictor & All admissions & $\begin{array}{l}\text { Critical care } \\
\text { mortality }\end{array}$ & $\begin{array}{l}\text { Univariate OR } \\
(95 \% \mathrm{CI})\end{array}$ & $\begin{array}{l}\text { Univariate } \\
p \text {-value }\end{array}$ & $\begin{array}{l}\text { Multivariate OR } \\
(95 \% \mathrm{CI})\end{array}$ & $\begin{array}{l}\text { Multivariate } \\
p \text {-value }\end{array}$ \\
\hline Age (years), mean (SD) & $43.7(16.6)$ & $47.6(16.5)$ & $1.02(1.001-1.04)$ & 0.04 & $1.03(1.01-1.06)$ & 0.01 \\
\hline Male, $n(\%)$ & $198(77.6)$ & $38(66.7)$ & $0.79(0.42-1.46)$ & 0.45 & - & - \\
\hline ASA category, $n(\%)$ & $n=254$ & $n=56$ & & & & \\
\hline 1 & $46(18.1)$ & $6(10.7)$ & Reference & & Reference & - \\
\hline 2 & $47(18.5)$ & $8(14.3)$ & $1.37(0.43-4.31)$ & 0.59 & $1.59(0.43-6.0)$ & 0.49 \\
\hline 3 & $102(40)$ & $19(33.9)$ & $1.53(0.57-4.12)$ & 0.40 & $1.12(0.36-3.46)$ & 0.85 \\
\hline 4 & $53(20.8)$ & $21(38.5)$ & $4.38(1.58-12.1)$ & 0.005 & $3.06(0.96-9.73)$ & 0.06 \\
\hline 5 & $6(2.4)$ & $2(3.6)$ & $3.33(0.49-22.3)$ & 0.22 & $1.21(0.14-10.7)$ & 0.87 \\
\hline Grade of surgery, $n(\%)$ & $n=250$ & $n=56$ & & & & \\
\hline Minor & $21(8.4)$ & $5(8.9)$ & Reference & & - & - \\
\hline Intermediate & $76(30.4)$ & $19(33.9)$ & $1.07(0.34-3.30)$ & 0.91 & - & - \\
\hline Major & $153(61.2)$ & $32(57.1)$ & $0.85(0.29-2.49)$ & 0.85 & - & - \\
\hline Urgency of surgery, $n(\%)$ & $n=253$ & $n=57$ & & & & \\
\hline Elective & $56(22.1)$ & $3(5.3)$ & Reference & & Reference & - \\
\hline Urgent & $82(32.4)$ & $16(28.1)$ & $4.28(1.19-15.48)$ & 0.03 & $4.14(1.04-16.5)$ & 0.04 \\
\hline Emergency & $115(45.4)$ & $38(66.7)$ & $8.72(2.56-29.72)$ & 0.01 & $6.89(1.79-26.6)$ & 0.005 \\
\hline \multicolumn{7}{|l|}{ Surgical specialty, $n(\%)$} \\
\hline Orthopaedic & $23(9.0)$ & $2(3.5)$ & $0.31(0.70-1.35)$ & 0.31 & - & - \\
\hline Gynaecological & $10(3.9)$ & $0(0)$ & - & 0.08 & - & - \\
\hline Vascular & $21(8.2)$ & $7(12.3)$ & $1.84(0.71-4.80)$ & 0.21 & - & - \\
\hline Upper GIT & $32(12.5)$ & $11(19.3)$ & $2.02(0.91-4.48)$ & 0.09 & - & - \\
\hline Lower GIT & $36(14.1)$ & $13(22.8)$ & $2.25(1.06-4.79)$ & 0.04 & $2.12(0.93-4.84)$ & 0.08 \\
\hline Hepatobiliary & $8(3.1)$ & $2(3.5)$ & $1.16(0.23-5.93)$ & 0.86 & - & - \\
\hline Plastic & $9(3.5)$ & $3(5.3)$ & $1.78(0.43-7.34)$ & 0.43 & - & - \\
\hline Urological & $10(3.9)$ & $0(0)$ & - & 0.08 & - & - \\
\hline Thoracic & $17(6.7)$ & $0(0)$ & - & 0.02 & - & - \\
\hline Other & $22(8.6)$ & $8(14.0)$ & $2.15(0.85-5.41)$ & 0.11 & - & - \\
\hline Primary indication for surgery, $n(\%)$ & $n=253$ & $n=57$ & & & & \\
\hline Non-communicable & $105(41.5)$ & $16(28.1)$ & - & Reference & - & - \\
\hline Injury & $103(40.7)$ & $24(42.1)$ & $1.69(0.84-3.41)$ & 0.14 & - & - \\
\hline Infective & $45(17.8)$ & $17(29.8)$ & $3.38(1.51-7.55)$ & 0.003 & $2.12(0.93-4.82)$ & 0.07 \\
\hline COPD/asthma & $28(11.4)$ & $6(11.1)$ & $0.94(0.36-2.44)$ & 0.89 & - & - \\
\hline HIV-positive/AIDS & $20(8.2)$ & $5(9.1)$ & $1.17(0.40-3.37)$ & 0.78 & - & - \\
\hline $\begin{array}{l}\text { SOFA within 1st } \mathrm{h} \\
\text { of admission }\end{array}$ & $10(3)$ & $11(3)$ & $1.32(0.96-1.82)$ & 0.09 & - & - \\
\hline
\end{tabular}


A significant number of patients died after being discharged from critical care. Several deaths may have been expected in conditions considered to be irreversible, and palliative end-of-life care may have ensued. However, unexpected deaths after ICU discharge may point to several issues, including a lack of step-down facilities, inappropriate, forced or early discharges, and poor monitoring and identification of deterioration in the ward. Considering the financial implications and resources invested in ICU patients, this is a critical question that requires investigation.

Finally, the strongest independent predictor of mortality was urgent and emergency surgery. Although lower GIT surgery and infection were not statistically significant, it is possible that their importance might have been identified in a larger cohort. These findings highlight the need to improve preventive strategies aimed at reducing trauma and communicable disease, promoting healthseeking behaviour among our patient population, and improving the peri-operative risk stratification, risk modification and optimisation of these patients.

\section{Study limitations}

This large, multicentre study of critically ill surgical patients does not represent the full burden of disease that is presented to critical care units, as critically ill obstetric patients were excluded. Furthermore, it does not represent most district hospitals or private healthcare facilities in SA. These units may encounter a different surgical population and patient pathologies.

The SOFA score was used to describe the severity of organ dysfunction in this cohort. While other scores may be preferable, e.g. Acute Physiology and Chronic Health Evaluation II (APACHE II), ${ }^{[25]}$ we unfortunately did not have the data to present APACHE scores. SOFA is a well-validated scoring system for many critically ill patient populations and has been used by other authors in presenting the severity of organ dysfunction on admission. ${ }^{[26,27]}$

\section{Conclusion}

Urgent and emergency surgery and unplanned admissions are strongly associated with critical care mortality in SA. These data suggest that limited critical care resources and poor risk stratification or late triage of patients at risk may further compromise survival. The provision of appropriate postoperative high care beds could substantially reduce the pressure on critical care resources. The burden of trauma and inadequately managed sepsis, both nosocomial and from the community, is substantial. Programmes and interventions directed towards sepsis prevention with early detection and treatment are priorities in future trial designs involving surgical critical care in SA.

Acknowledgement. The study website was maintained by the Anaesthesia Network for South Africa (ANSA).

Author contributions. Neither the SA Society of Anaesthesiologists (SASA) nor ANSA had any role in the study design, data acquisition, data analysis or writing of the article.

Funding. The study was funded by SASA and the Vascular Association of SA (VASSA).
Conflicts of interest. RP has given lectures and/or performed consultancy work for Nestlé Health Sciences, Medtronic, Edwards Lifesciences, and Masimo Inc., and is a member of the associate editorial board of the British Journal of Anaesthesia.

1. Adikhari NK, Fowler RA, Bhagwanjee S, Rubenfeld GD. Critical care and the global burden of critical illness in adults. Lancet 2010;376(9749):1339-1346. https://doi.org/10.1016/S0140-6736(10)60446-1

2. Gordon K, Allorto N, Wise R. Analysis of referrals and triage patterns in a South African metropolitan adult intensive care service. S Afr Med J 2015;105(6):491-495. https://doi.org/10.7196/samj.9007

3. Biccard BM, Madiba TE; on behalf of the South African Surgical Outcomes Study Investigators. The South African Surgical Outcomes Study: A 7-day prospective observational cohort study. S Afr Med J South African Surgical Outcomes Study: A 7-day prospectiv
2015;105(6):465-475. https://doi.org/10.7196/samj.9435

4. Pearse RM, Moreno RP, Bauer P, et al. Mortality after surgery in Europe: A 7-day cohort study. Lancet 2012;380(9847):1059-1065. https://doi.org/10.1016/s0140-6736(12)61148-9

5. Elm Von E, Altman DG, Egger M, et al. The Strengthening and Reporting of Observational Studies in Elm Von E, Altman DG, Egger M, et al. The Strengthening and Reporting of Observational Studies in
Epidemiology (STROBE) statement: Guidelines for reporting observational studies. PLoS Med 2007; Epidemiology (STROBE) statement: Guidelines for reporting
4(10):e296. https://doi.org/10.1371/journal.pmed.0040296

4(10):e296. https://doi.org/10.1371/journal.pmed.0040296
6. Acute Kidney Injury Work Group. Kidney Disease: Improving Global Outcomes (KDIGO): Clinical practice guideline for acute kidney injury. Kidney Int 2012;2(Suppl):1-138. https://doi. org $/ 10.1159 / 00033978$

7. Vincent JL, Moreno R, Takala J, et al. The SOFA (Sepsis-related Organ Failure Assessment) score to describe organ dysfunction/failure. Int Care Med 1996;22(7):707-710. https://doi.org/10.1007/ s001340050156

8. Finkielman JD, Morales IJ, Peters SG, et al. Mortality rate and length of stay of patients admitted to the intensive care unit in July. Crit Care Med 2004;32(5):1161-1165. https://doi.org/10.1097/01. ccm.0000126151.56590.99

9. Esteban A, Anzueto A, Frutos F, et al., for the Mechanical Ventilation International Study Group. Characteristics and outcomes in adult patients receiving mechanical ventilation: A 28-day international study. JAMA 2002;287(3):345-355. https://doi.org/10.1001/jama.287.3.345

0. World Health Statistics. 2010. https://books.google.co.za/books/about/World_Health_Statistics_2010. html?id=Z69vxfRfFIsC (accessed 20 March 2017).

1. Shisana O, Rehle T, Simbayi LC, et al. South African National HIV Prevalence, Incidence and Behaviour Survey, 2012. Cape Town, HSRC Press, 2014.

12. Cacala SR, Mafana E, Thomson SR, et al. Prevalence of HIV status and CD4 counts in a surgical cohort: Their relationship to clinical outcome. Ann R Coll Surg Engl 2006;88(1):46-51. https://doi. org/10.1308/003588406x83050

13. Madiba TE, Muckart DJJ, Thomson SR. Human immunodeficiency disease: How should it affect surgical decision making? World J Surg 2009;33(5):899-909. https://doi.org/10.1007/s00268-009surgical

14. Chen TL, Lin YC, Liao CC. Postoperative adverse outcomes after major surgery in HIV-infected patients: A nationwide matched cohort study. Eur J Anaesth 2014;3(1):7. https://doi.org/10.1097/00003643A nationwide mo601-00018

15. Chichom-Mefire A, Azabji-Kenfack M, Atashili J. CD4 count is still a valid indicator of outcome in HIV-infected patients undergoing major abdominal surgery in the era of highly active antiretroviral therapy. World J Surg 2015;739(7):1692-1699. https://doi.org/10.1007/s00268-015-2994-8

16. Spelman DW. Hospital-acquired infections. Med J Aust 2002;176(6):286-291.

16. Spelman DW. Hospital-acquired infections. Med Aust 2002;176(6):286-291.
17. Soleto Pirard M, Boelaert M, et al. Incidence of surgical-site infections and the validity of the National Nosocomial Infections Surveillance System risk index in a general surgical ward in Santa National Nosocomial Infections Surveillance System risk index in a general surgical ward in Sant
Cruz, Bolivia. Infect Control Hosp Epidemiol 2003;24(1):26-30. https://doi.org/10.1086/502111

18. Ferreira FL, Bota DP, Bross A, et al. Serial evaluation of the SOFA score to predict outcome in critically 8. Ferreira FL, Bota DP, Bross A, et al. Serial evaluation of the SOFA score to predict outco
ill patients. JAMA 2001;286(14):1754-1758. https://doi.org/10.1001/jama.286.14.1754

19. Thakar CV, Christianson A, Freyberg R, et al. Incidence and outcomes of acute kidney injury in intensive care units: A Veterans Administration study. Crit Care Med 2009;37(9):2552-2558. https:/ doi.org/10.1097/ccm.0b013e3181a5906f

20. Joannidis M, Metnitz B, Bauer P, et al. Acute kidney injury in critically ill patients classified by AKIN versus RIFLE using the SAPS 3 database. Int Care Med 2009;35(10):1692-1702. https://doi. org/10.1007/s00134-009-1530-4

21. Cooper BA, Branley P, Bulfone L, et al. A randomized, controlled trial of early versus late initiation of dialysis. N Engl J Med 2010;363(7):609-619. https://doi.org/10.1056/nejmoa1000552

22. Karvellas CJ, Farhat MR, Sajjad I, et al. A comparison of early versus late initiation of renal replacemen therapy in critically ill patients with acute kidney injury: A systematic review and meta-analysis. Crit Care 2011;15(1):72. https://doi.org/10.1186/cc10061

23. Gaudry S, Hajage D, Schortgen F, et al. Initiation Strategies for Renal-Replacement Therapy in the Intensive Care Unit. N Engl J Med 2016;375:122-133. https://doi.org/10.1056/NEJMoal603017.

24. Zarbock A, Kellum JA, Schmidt C, et al. Effect of early vs delayed initiation of renal replacemen therapy on mortality in critically ill patients with acute kidney injury: The ELAIN Randomized Clinical Trial. JAMA 2016;315(20):2190-2199. https://doi.org/10.1001/jama.2016.5828

25. Knaus WA, Draper EA, Wagner DP, Zimmerman JE. APACHE II: A severity of disease classification system. Crit Care Med 1985;13(10):818-829. https://doi.org/10.1097/00003246-198510000-00009

26. Vosylius S, Sipylaite J, Ivaskevicius J. Sequential organ failure assessment score as the determinant of outcome for patients with severe sepsis. Croat Med J 2004;45(6):715-720.

27. Moreno R, Vincent JL, Matos R, et al. The use of maximum SOFA score to quantify organ dysfunction/ failure in intensive care. Results of a prospective, multicentre study. Int Care Med 1999;25(7):686-696. https://doi.org/10.1007/s001340050931

Accepted 15 February 2017 


\section{Appendix 1. Members of the SASOS group}

SASOS Writing Committee. P Alexandris, D R Bhagwandass, B M Biccard, K D Boffard, G A Buga, E Cloete, A Coetzee, L Cronje, A Daffala, B J Diedericks, R S du Toit, T M Esterhuizen, C Fourie, A G Mahomed, P D Gopalan, F Guidozzi, R W Hewson, A Hoeft, I Joubert, D Kahn, M Klipin, H-L Kluyts, Z Koto, B G Lindeque, A C Lundgren, R Machekano, T E Madiba, L R Mathivha, T R Mokoena, S Monokoane, R Moreno, D F Morrell, B Mrara, M Ntlhe, E E Oosthuizen, R M Pearse, S S Pillay, J P Pretorius, A Rantloane, A Rhodes, G Richards, R Rodseth, M Sebitloane, M Smith, S Spijkerman, M G L Spruyt, J Swanevelder, $\mathrm{H}$ van der Merwe, B L Warren, $\mathrm{P}$ H Wessels, on behalf of the SASOS investigators.

SASOS Steering Committee. P Alexandris, D R Bhagwandass, B M Biccard, K D Boffard, G A Buga, A Coetzee, A Daffala, B J Diedericks, R S du Toit, T M Esterhuizen, C Fourie, A G Mohamed, P D Gopalan, F Guidozzi, R W Hewson, A Hoeft, I Joubert, D Kahn, H-L Kluyts, Z Koto, B G Lindeque, A C Lundgren, R Machekano, T E Madiba, L R Mathivha, T R Mokoena, S Monokoane, R Moreno, D F Morrell, B Mrara, M Ntlhe, E Oosthuizen, R M Pearse, J P Pretorius, A Rantloane, A Rhodes, G Richards, R Rodseth, M Sebitloane, M Smith, S Spijkerman, M G L Spruyt, J Swanevelder, H van der Merwe, B L Warren, P Wessels, on behalf of the SASOS investigators.

\section{Appendix 2. SASOS investigators and SASOS hospital sites}

Eastern Cape Province. Cecilia Makiwane Hospital: K A Bhat*, B Dokolwana; Frere Hospital: M Coltman ${ }^{\star}$, G Westcott; Livingstone Hospital: L Friedman, D Schmidt*, S Venter; Nelson Mandela Academic Hospital: A Dhaffala, B Mrara*, B Thomas, A Usenbo; Port Elizabeth Provincial Hospital: P Alexandris*, T Serdyn.

Free State Province. Dihlabeng Regional Hospital: W J Selfridge, A J Stals*, W van Zyl, J Vermaak; National Hospital, Pelonomi Regional Hospital and Universitas Academic Hospitals: W Barret, M Bester, J de Beer, J Geldenhuys, H Gouws, J H Potgieter*, M Strydom, E Turton.

Gauteng Province. Charlotte Maxeke Johannesburg Academic Hospital: M Klipin, I Mare, V Morford*, O Smith; Chris Hani Baragwanath Academic Hospital: Y Adam, W Alhazel, K Antwi, A Atiya, M Ayuk, J Baladakis, S Baloyi, S Barka, N Biyase, N Braam, A Buitenweg, H Burcan, A Cohen, S Cuthbert, Z Dadabhay, S Davies, I du Preez, S Dulabh, W Edridge, S French, M Gayaparsad, J HamuySosa, N Hendricks, T Hlongwane, R Husein, N Hutton, T Jackson, E Jacobs, J Jocum, N Khan, H Khan, A Kiss, V Kumalo, F Lambat, A Lekha, T Leonard, D Leshaba, D Liakos, M Lindy, A C Lundgren, L T Lushiku, K Madiba, N Madima, S Maswime, R Mathiva, J J Mahlangu, M Maisto, P Makwanya, S Maswime, L Matsane, C Mitchell, B Monzon, D Moodley, J Moutlana, G Mukucha, N Murugan, J Nana, N Ndlazi, D Nel${ }^{*}$, G Nethathe, M Nxumalo, Y Nyathela, S Nyimbana, S Omar, J Omoshoro-Jones, A Oosthuizen, E Patel, D Prem, R Pretorius, C Quan, T Ranyaka, K Rathinasamy, C Redelinghuys, N Rikhotso, C Sanders, C Segal, R Setzen, R Sheikh, Z Soni, J Steynberg, M Stubbs, O Tinubu, S Toich, S Tshukutsoane, J Vally, A van der Walt, $\mathrm{N}$ van der Walt, E van Greunen, D van Niekerk, L Variawa, S Veeren, C von Creytz, J Wagner, J Yogeswaram; Dr George Mukhari Hospital: D R Bhagwandass, S L L K Dlamini, A Fourie, A Goolam Mahomed, J Joseph, N Kumar, T C Maganyane, M Z Koto*, S R Motilall; Helen Joseph Hospital: G Cavedon*, K Fisher, H Jahrani, R Maja, J Malumalu, E Semenya, N Zondi; Kalafong Hospital: A Alberts,
F Botha, J de Bruin, S Carrim, T Chagwiza, S East, P J H L Fourie, A Joubert, H Kluyts*, J Khosa, T Luvhengo, H Maakamedi, R Maharaj, S Motsitsi, J P Mulder, S Naidoo, H Schutte, A Vlok, M Voigt; Rahima Moosa Mother and Child Hospital: S Chetty*, M de Jager; Steve Biko Academic Hospital: Z Abdool, M Aphane, H J C du Plessis, P R Jujuju, E Moshokoa, M Ngcelwane, L M Ntlhe*, J P Pretorius, S Spijkerman, M Tshifilaro.

KwaZulu-Natal Province. Addington Hospital: M M F Ansermeah, A Dunpath, J Fabian, M Khan, M Maritz, M Naidoo, S Rambarran, P Reddy, U Singh*; Edendale Hospital: N Allorto, D Bishop* ${ }^{\star}$ P M Builu, C Cairns, A Dasrath, J de Wet, M den Hoedt, B Grey, M Hayes, B Kusel, N Shangase, R Wise; Grey's Hospital: S Cacala, Z Farina, V Govindasamy*, C-H Kruse, C Lee, L Marais, T D Naidoo, C Rajah, R Rodseth, L Ryan, R von Rhaden; King Dinuzulu Hospital: G Alexander, N Brouckaert, B Freeman*, S Goga; King Edward VII Hospital: R Chetty, S Chirkut, L Cronje ${ }^{\star}, \mathrm{K}$ de Vasconcellos, N Z Dube, N S Gama, G Green, R Green Thompson, S Mewa Kinoo, P Kistnasami, K Maharaj, M S Moodley, S Mothae, R Naidoo, A Noorbhai, V Raghubar, J Reddy, A Singh, D Skinner, M Smith, B Singh; Inkosi Albert Luthuli Central Hospital: S Adam, C Alphonsus, Y Ameer, F Anderson, S Basanth, S Bechan, C Bhula, B M Biccard*, T Biyase, J Bruce, I Buccimazza, J Cardosa, C Y Chen, B Daya, L Drummond, A Elabib, E H Abdel Goad, I E Goga, R Goga, T C Hardcastle, R Harrichandparsad, R E Hodgson, J Jordaan, N Kalafatis, C Kampik, T Kisten, A T Landers, E Loots, R Madansein, A Madaree, T E Madiba, V T Manzini, M Mbuyisa, R Moodley, M Msomi, D J J Muckart, I Mukama, D Naidoo, R Naidoo, T K Naidu, S Ntloko, E Padayachee, L Padayachee, M Phaff, B Pillay, D Pillay, L Pillay, A Ramnarain, S R Ramphal, P Ryan, A Saloojee, M Sebitloane, N Sigcu, J Taylor, A Torborg, L Visser; Ladysmith Hospital: I Asmal, M Gasa, G Madombwe*, S Mohanadasan; Lower Umfolozi District War Memorial Hospital: Y Bwambale ${ }^{\star}$, N Mayat, L Mlambo-Williams; Madadeni and Newcastle Hospitals: S Cheddie, A Elghobasy, R Hurley*, M Kopieniak, N M Naidoo; Mahatma Gandhi Hospital: M Ahmed, N Amod, M B Greenwood, B Hira, D Kesene, K Laubscher, D Naidoo, N A Mahomedy, S Moosa, V Moonsamy, S Reddy, D Rungan ${ }^{\star}$, A S Sader, A Thotharam; Ngwelezane Hospital: R Misra, M Naidoo, Y Selibean, S Sewpersad ${ }^{\star}$, S Sham, J Wessels; Northdale Hospital: K A Adu, J T Liphaphang, D Maiwaid*, M Marais, T Mniki; Port Shepstone Hospital: C Africander, T Bejia, S Blakemore*, M Botes, B Bunwarie, C B Hernandez, M A A Jeeraz, D Legutko, A Lopez, J de Meyer, T Muzenda, N Naidoo*, M Patel, H Pentela, M Junge, N Mansoor, L Rademan, P Scislowski, I Seedat, B van den Berg, D van der Merwe, S van Wyk; Prince Mshiyeni Hospital: K Govender*, D Naicker, R Ramjee, M Saley; R K Khan Hospital: A Ganesh, A Gounden, C. Houston, S Mould, K Naidoo, A Nansook, N Rorke*, S Tarr; St Aidan's Hospital: T Ramsamy; Stanger Hospital: W Kuhn, R Matos-Puig*, Z Moolla*.

Limpopo Province. Pietersburg Provincial Hospital: M A Baloyi, L Bashiya, A Bogoslovskiy, M I Diale, N Escober, M E Gonzalez, D Horzstynski, P K Legodi, M E Maboya, R K Maila, A Z Machowski, M V Mashile, O R Masia, J N Masipa, M S L Masotja, R Mavhungu, M S Mokoena, T Mukwevho, S Z Mzezewa, E V Neluheni, D S Nesengani, S Omoding, L O Orjiako, N Perez, S S Pillay*, M Rambau, R Ramos, H Raura, B Ryabchiy, T O Sadiki, M D Seshibe, O S Taran, E N Thwala, B Woldu.

Mpumalanga Province. Rob Ferreira Hospital: C Chikwiri, C A Cumbi, M Dalton, N P Godi, S B Ibirogba, P R Jujuju*, N R Mahlalela, F A Steyn, A J Troskie, J Vosloo. 
North West Province. Job Shimankana Tabane Hospital: T D Kibibi, A J M Lubamba, S J Moumakoe*, K Pege, W Seboni.

Northern Cape Province. Kimberley Hospital Complex: P Anderson, A Conradie, M de Swardt ${ }^{\star}$, M de Villiers, J Eikman, R Liebenberg, J Mouton, A Paton, L van der Merwe, C Wilscott-Davids.

Western Cape Province. Eerste River Hospital: H Maharaj ${ }^{\star}$, C Strauss; George Provincial Hospital: D Tait, M Jordaan*; Groote Schuur Hospital: K Bergh, M E Casey, E Cloete*, R Dyer, S Jeffrey, D Khan, W Makhambeni, D C Nolte, G Picken, J Swanevelder, D Visu; Helderberg and Karl Bremer Hospitals: M Jaworska*; Khayelitsha District
Hospital: H Lalkhen, H Maharaj*, S Serfontein; Mitchells Plain Hospital: T Biesman-Simons, S Carolissen, S Erasmus, J Holm, L Hoole, J Roos ${ }^{*}$, R Sauls, I Slabber, J van Schoor; Paarl Hospital: G Davies*, V Koller; Somerset Hospital: A Reed ${ }^{*}, H$ Steinhaus; Tygerberg Hospital: I Conradie*, R Dannatt, M du Plessis, L du Preez, K du Toit, C Fourie, C Gildenhuys, A Gretschel, Y Loots, P Marwick, Y Ngcwama, R Rautenbach, , P Scheepers, N Terblanche, F H van der Merwe, R van Rensburg, A Vermeulen, S Vlok, S Watcham; Victoria Hospital: N Fuller*; Worcester Hospital: W Christian, R Duvenage, T Franken, G Gobetz, W Hansen, T Kambarami, M Kok, J Janse van Vuuren.

${ }^{*}$ Lead hospital investigator. 